DOI 10.31558/2307-2318.2019.4.3

УДК 336.143.2:352

Лактіонова О.А., д.е.н., доцент, Донецький національний університет імені Василя Стуса

Коберник Т.А., магістр, Донецький національний університет імені Василя Стуса

\title{
АНАЛІЗ ЧИННИКІВ ДОСТУПУ ДО КАПІТАЛУ ТА ІНФРАСТРУКТУРИ ФІНАНСОВОГО ЗАБЕЗПЕЧЕННЯ МАЛОГО БIЗНЕСУ В РЕГIОНI
}

У статті досліджено чинники доступу до капіталу та інфраструктури фінансового забезпечення малого бізнесу на рівні регіону. Здійснено аналіз відмінностей у вартості капіталу для малого, середнього та великого бізнесу, розвитку кредитного ринку для потреб малих підприємств в розрізі областей України. Проведено оцінку комфортності ведення бізнесу з точки зору доступності фінансування у м. Вінниці на основі методики, розробленої в рамках проекту «Партнерство для розвитку міст» (Проект ПРОМІС). Доступність фінансових ресурсів визначено на основі оцінки ринку банківських послуг, розповсюдженості практик фінансування за допомогою бізнес асоціацій та розвиненості місцевих бюджетних програм для підприємництва.

Ключові слова: доступ до капіталу, інфраструктура фінансового забезпечення, малий бізнес, комфортність ведення бізнесу.

Рис.-7, Літ. -10.

\section{Лактионова А.А., Коберник Т.А.}

\section{АНАЛИЗ ФАКТОРОВ ДОСТУПА К КАПИТАЛА И ИНФРАСТРУКТУРЫ ФИНАНСОВОГО ОБЕСПЕЧЕНИЯ МАЛОГО БИЗНЕСА В РЕГИОНЕ}

В статье исследованы факторы доступа к капиталу и инфраструктуры финансового обеспечения малого бизнеса на уровне региона. Осуществлен анализ различий в стоимости капитала для малого, среднего и крупного бизнеса, развития кредитного рынка для нужд малых предприятий в разрезе областей Украины. Проведена оценка комфортности ведения бизнеса с точки зрения доступности финансирования в г.. Виннице на основе методики, разработанной в рамках проекта «Партнерство для развития городов» (Проект ПРОМИС). Доступность финансовых ресурсов определены на основе оценки рынка банковских услуг, распространенности практик финансирования с помощью бизнес ассоциаций и развитости местных бюджетных программ для предпринимательства.

Ключевые слюва: доступ к капиталу, инфраструктура финансового обеспечения, малый бизнес, комфортность ведения бизнеса.

Laktionova A., Kobernyk T.

ANALYSIS OF THE FACTORS OF ACCESS TO CAPITAL AND INFRASTRUCTURE OF SMALL BUSINESS IN THE REGION

The article explores the factors of access to capital and infrastructure for small business financial support at the regional level. The analysis of differences in the cost of capital for small, medium and large businesses, the development of credit market for the needs of small businesses in the cross-section of Ukraine. The comfort of doing business in terms of accessibility of financing in Vinnitsa was conducted on the basis of the methodology developed within the framework of the Partnership for Urban Development project (PROMIS project). 
The availability of financial resources is determined on the basis of an assessment of the banking services market, the prevalence of financing practices through business associations and the development of local budget programs for entrepreneurship.

Keywords: access to capital, financial security infrastructure, small business, convenience of doing business.

Постановка проблеми. Актуальність проблем доступу до капіталу малих підприємств в Україні визначається неефективністю фінансового та, зокрема, кредитного ринку для суб'єктів малого бізнесу, яка є притаманною як для країн із розвинутими ринковими відносинами, так і для економіки України. В цьому аспекті розвиток механізмів інфраструктури фінансового забезпечення є об'єктивною основою зниження фінансової асиметрії та збільшення інвестицій в малий бізнес.

Аналіз останніх досліджень і публікацій. Значний вклад у вирішення даної наукової проблеми внесли вітчизняні та зарубіжні вчені, такі, як: Рекуненко I. I. [1], Кугій А. А., Сокотенюк С. М. [2], Гацька Л. П., Журавський В. Л.[3]

Виділення невирішеної проблеми. Не зважаючи на вагомі наукові результати, отримані вченими, наразі розвиток інфраструктури розширення доступу до капіталу залишається недостатньо дослідженим як в теоретичному так і в практичному аспектах. Активний науковий інтерес викликають і питання нерівномірності розвитку кредитного ринку для малого бізнесу, що виникають на регіональному рівні.

Метою статті $\epsilon$ визначення рівня та чинників, що формують доступ до капіталу для малого бізнесу на локальному рівні.

Виклад основного матеріалу. Зовнішнє фінансування - $є$ важливим ресурсом, що дозволяє компаніям вести свій бізнес, модернізувати своє обладнання або розширювати свою діяльність, підвищувати свою конкурентоспроможність. Малий та середній бізнес зазвичай є більш обмеженими у доступі до фінансових ресурсів, ніж великий, для багатьох підприємств високі процентні ставки та вимоги до застави роблять доступ до банківської позики вкрай дорогим. Такі проблеми виникають і у сфері банківських послуг для започаткування бізнесу та його розширення.

Виходячи 3 джерел фінансування суб'єктів малого бізнесу, протягом 3-х років, капіталу на одного суб'єкта мав тенденцію до зниження (рис.1) з 10,70 млн. грн. у 2016р. до 2,5 млн. грн. у 2018p. Здебільшого це відбулося за рахунок падіння поточних зобов'язань, який $є$ головним джерелом фінансування. Доступ як до власного, так і до позикового капіталу є суттєво обмеженим та найменш гнучким із досить повільним зростанням.

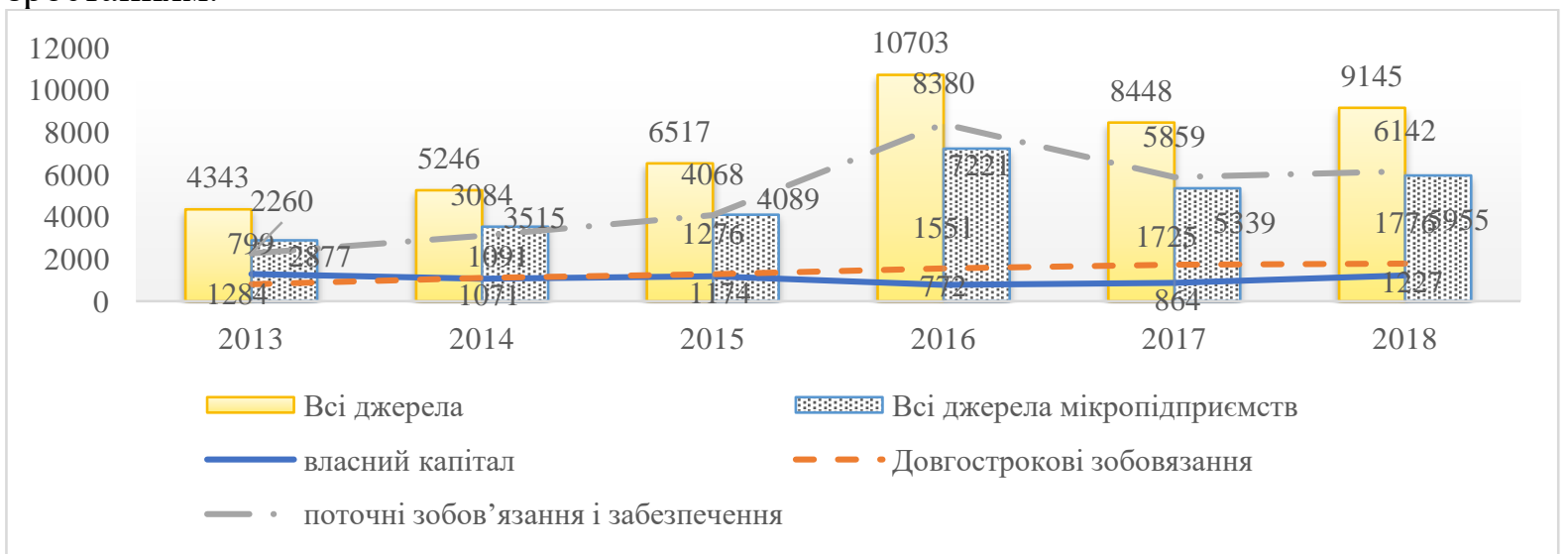

Рисунок 1 - Фінансування малого бізнесу та мікропідприсмств, грн. на одне підприсмство (розраховано на основі [4]) 
Відповідно до звіту оцінки політики щодо малого бізнесу у країнах Східного партнерства ОЕСР розрив за показниками доступу до фінансування малих підприємств складає від тах-му 36\%, найбільше за індикатором відхилення в негативний бік: схеми гарантування кредитів (67\%), венчурне фінансування (72\%) та його законодавче забезпечення (71\%), моніторингом та оцінка фінансової грамотності (80\%), банківське фінансування (59\%).

Серед рекомендацій ОЕСР в сфері стимулювання та розширення доступу до фінансування були такі: впровадження стійкої ресурсної бази для банків в національній та іноземній валюті; підтримка банківської конкуренції для формування ініціативи для банків і пропозиції більш конкурентними ставками банківських послуг на нових ринках; зниження ринкових недосконалостей на основі таргетування схем гарантування кредитів для малого бізнесу і посилення небанківських джерел фінансування; покращення фінансової грамотності серед населення [5].

Схеми гарантій кредитування можуть допомогти малому бізнесу подолати кредитні обмеження, інтегрувати малий бізнес у формальний ринок кредитування за рахунок зменшення кредитного ризику банку. Кредитні гарантії як частина програм підтримки малого бізнесу існує майже у всіх країнах Східного партнерства, крім Азербайджану, де основним каналом підтримки є компенсація процентних ставок, що надається Національним фондом для підтримки підприємництва. Схеми кредитних гарантій в регіоні, як правило, тісно співпрацюють 3 місцевими банками, але участь приватного сектору в їх управлінні та ефективність надання послуг у багатьох випадках може бути підвищена. В Україні кредитні гарантії існують вже певний час, наразі розглядається схема гарантій із участю приватного сектору.

Один 3 прикладів доброї практики був в Естонії, де уряд створив «kredEx», самостійну фінансову установу, що пропонує гарантії позики, щоб допомогти бізнесу отримати доступ до фінансів, необхідних для інвестиційного зростання. Ключовий фактор успіху kredEx полягав в тому, що проводився послідовний моніторинг та оцінка зусиль для забезпечення адекватного впливу та просвітницької діяльності підприємств. Тільки у 2014 році kredEx надав гарантії на суму 68 млн. євро, що допомогло 393 компаніям отримати доступ до фінансів. KredEx надає гарантії до 75\% фінансових продуктів, пропонованих банками-партнерами та лізинговим компаніям з контрактами у розмірі 1\% від гарантованої суми та мінімальних гарантійних платежів 0,4\% -1,7\%, залежно від фінансового продукту. Надання гарантій передбачає широкий спектр цілей фінансування [4].

Інформаційна асиметрія між кредитором та позичальником може бути зменшена шляхом встановлення всебічної та надійної системи кредитної інформації. Крім того, сприяння формуванню на рівні малого бізнесу навичок бізнес-планування та управління фінансами, робить їх більш привабливими клієнтами для постачальників фінансових послуг. Крім сфери банківського кредитування уряди також можуть сприяти розвитку i альтернативних галузей фінансування - мікрофінансуванню, лізингу та факторингу шляхом створення адекватних правових механізмів, нагляду та підвищенню рівня обізнаності про спектр варіантів фінансування, доступних для малого та середнього бізнесу. При відносно високих вимогах до застави та процентних ставках багато МСП не відповідають вимогам банків щодо кредитування, а тому не можуть отримати необхідне фінансування, інвестувати та розвивати свій бізнес. Небанківські джерела фінансування можуть відігравати важливу роль, доповнюючи банківське фінансування та пропонуючи альтернативи для малого та середнього бізнесу. 
Ефективність функціонування таких схем залежить від їх ретельного опрацювання. Одним із завдань $\epsilon$ підтримка приватного сектору у забезпеченні фінансових послуг за умови не порушення ринкової рівноваги. В іншому випадку вони ризикують витіснити приватний сектор і заробити підприємства залежними від постійної державної або місцевої підтримки у доступі до фінансування.

Враховуючи високий рівень ризику, пов'язаний з неперевіреними бізнес-моделями та відсутністю достатньої кредитної історії, банківське фінансування часто не $\epsilon$ альтернативою для інноваційних стартапів і швидко зростаючих підприємств, незважаючи на їх високий потенціал. Ці компанії виграють від добре функціонуючої системи венчурного капіталу.

Більшість країн Східного партнерства визнає фінансову грамотність ключовим пріоритетом розвитку регіону. Певні заходи були застосовані в СС для надання навичок, необхідних для створення та управління малим бізнесом, включаючи інформаційні портали та спеціальні навчальні програми. Однак, головним недоліком таких ініціатив $\epsilon$ поширена відсутність централізованої координації, нагляду та оцінки цих зусиль. Посилена увага до цієї сфери зробить різні зусилля уряду щодо фінансової грамотності більш прозорими та помітними для підприємців, значно підвищуючи їх привабливість та ефективність [4].

В Україні наявність фінансових обмежень для інвестиційної діяльності на рівні малого бізнесу підтверджується в частині вартості капіталу. Так, відповідно до даних НБУ, середні ставки за кредит для таких підприємств є вищими за аналогічні для середнього і великого бізнесу (рис. 2). Загальний розрив у вартості складав у 2017 році 1,8 в.п., у 2018 році 4,2 в.п., у 2019 році 9,3 в.п. Середня ціна капіталу для суб'єктів великого бізнесу за останні 3 роки склала $12 \%$, середнього - $17 \%$, малого - $18 \%$.

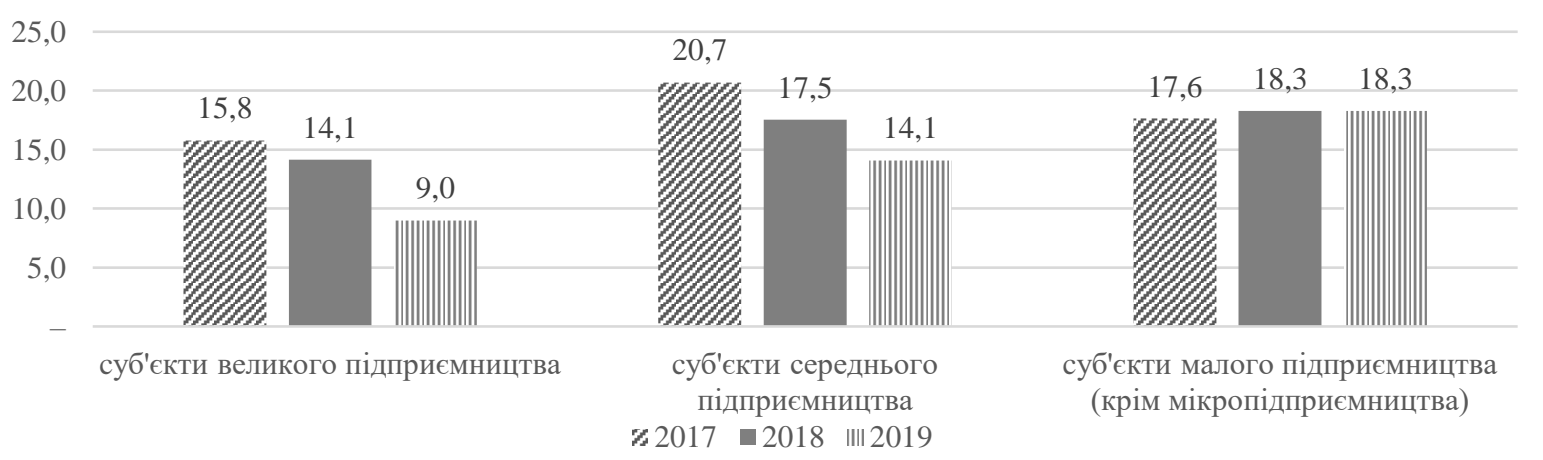

*складено на основі [6]

Рисунок 2 - Процентні ставки за кредит для великих, малих та середніх підприсмств в Україні, \%.

Загальні обсяги попиту на кредитні ресурси з боку реального сектору на рівні регіонів формуються на основі особливостей структури регіональної економіки за видами економічної діяльності а також ролі великого та малого бізнесу. Зазвичай регіони iз більшим валовим регіональним продуктом (ВРП) споживають більші обсяги позикових ресурсів. Разом із тим виявлена тенденція у співвідношенні частки кредитування та ВРП по регіонах вказує на відсутність однозначної закономірності (рис. 2), очевидно, що на отримання таких результатів впливають можливості залучення капіталу великим бізнесом поза регіонами, а саме у фінансових центрах країни де розташовано головні офіси більшості вітчизняних банків. Таким чином на Київську область та м. Київ у 2017 році припадало 75\% кредитів. На відміну від великих підприємств таких можливостей не мають малі суб'єкти господарювання. Так частка 
кредитування малого бізнесу в Україні складала на кінець 2017 року 13,4\% (на 01.10.2019 - 10\%). Якщо не враховувати фінансові та промислові центри країни (м. Київ, м. Харків, м. Дніпро), то на інші регіони припадає тільки $16 \%$ кредитного ринку в Україні. Така частка цілком співставна із обсягами кредитування малого бізнесу, який здебільшого залучає кошти на міста. Засновуючись на загальних обсягах кредитування на регіональних ринках найменше малий бізнес залучає ресурси Чернівецької, Закарпатської, Волинської, Донецької, Рівненської та Вінницької областей.

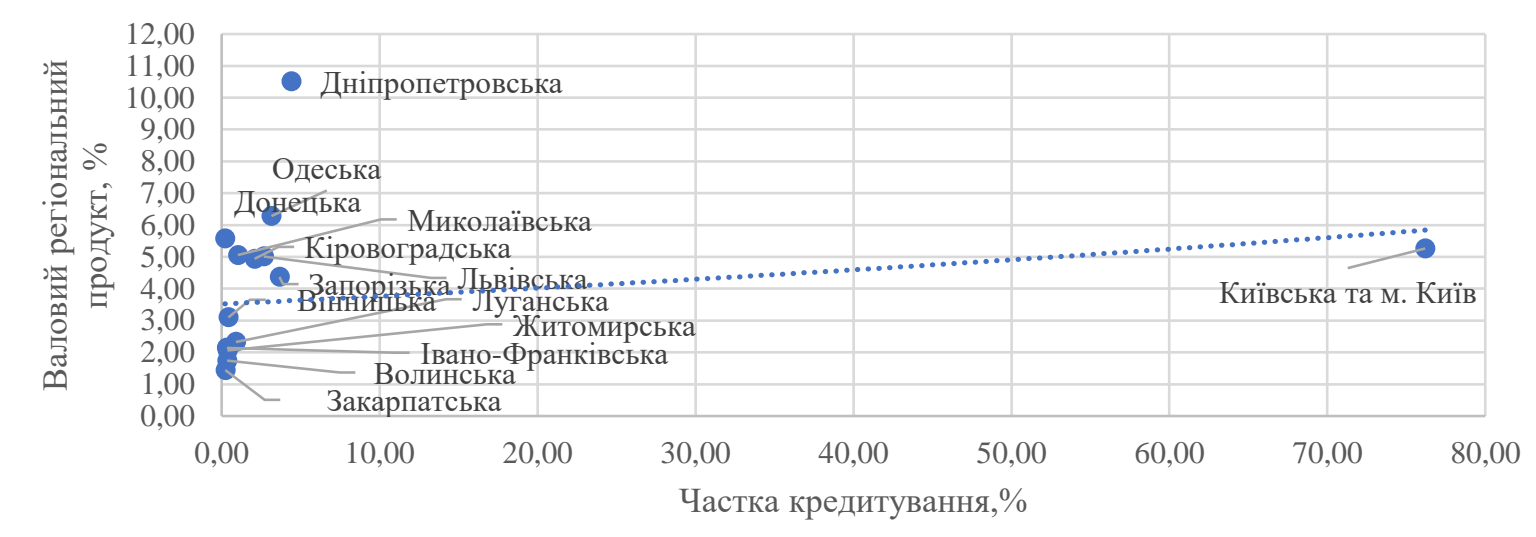

*складено на основі [6], [7]

Рисунок 3 - Частка кредитування в областях України до загальних обсягів ВРП (дані 2017 р.)

Доказом обмеженого доступу до фінансових ресурсів з боку малого бізнесу також свідчать пріоритети кредитування на регіональних ринках - співвідношення кредитів корпоративному сектору та домашнім господарствам (рис. 3). В таких областях як Житомирська, Закарпатська, Донецька, Чернівецька та Луганська кредитування населення переважає кредитування юридичних осіб. В інших областях таке співвідношення перевищує одиницю. Закономірно, що найбільший коефіцієнт мали Дніпропетровська, Київська, Запорізька, Харківська та Одеська області.

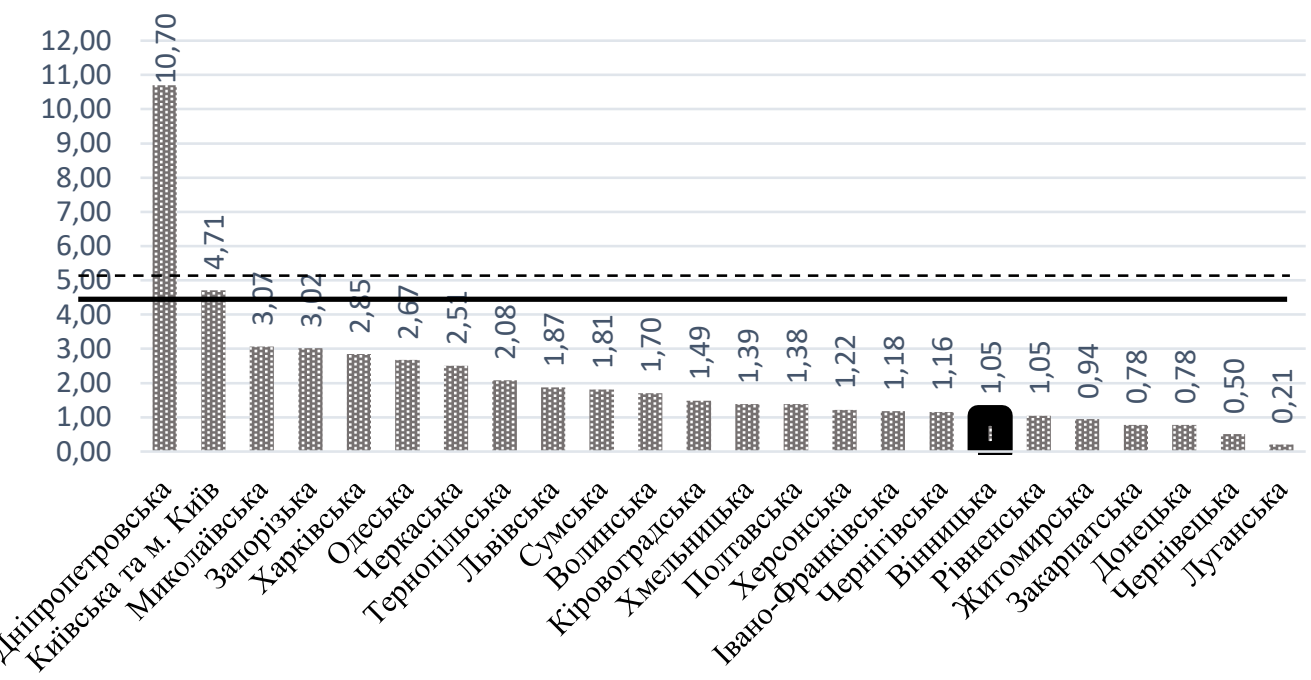

*складено на основі [6]

Рисунок 4 - Співвідношення кредитів корпоративному сектору та домашнім господарством у регіональному розрізі 
Для аналізу чинників доступу до капіталу малого бізнесу в Україні та виявлення проблем його інфраструктури на локальному рівні (м. Вінниця) застосуємо методику розроблену в рамках проекту «Партнерство для розвитку міст» (Проект ПРОМІС), яка оцінює комфортність ведення бізнесу з точки зору доступності фінансування [8]. Відповідно до цієї методики оцінювання проводиться за трьома сферами інфраструктури фінансового забезпечення: ринку банківських послуг, розповсюдженості практик фінансування із залученням бізнес асоціацій та місцевих бюджетних програм для підприємництва. У вибірку банків для оцінювання потрапили АТ КБ «Приватбанк» (займає 1 місце у рейтингу за активами банківських установ (517,6 млрд.грн.), ПАТ «Ощадбанк» (займає 2 місце у рейтингу за активами банківських установ (279,8 млрд.грн.), АТ «Укрсиббанк» (активи банку складають 53,6 млрд.грн.), АТ «АльфаБанк» (активи банку складають 72,9 млрд.грн.). Найкращі оцінки доступу до фінансування малого бізнесу отримав ПАТ «Ощадбанк» - 39 балів, на 2-му місці АТ КБ «Приватбанк» - 36 балів, АТ «Альфа-Банк» - 30 балів, АТ «Укрсиббанк» - 27 балів. Найбільш розвинутими послугами для малого бізнесу є кредитування оборотного капіталу, інвестиційне кредитування, кредитування бізнесу на пільгових умовах. Натомість найгірше розвинуті кредитування стартапів, кредитування експортноімпортних операцій, підвищення енергоефективності бізнесу та факторинг (рис. 5).

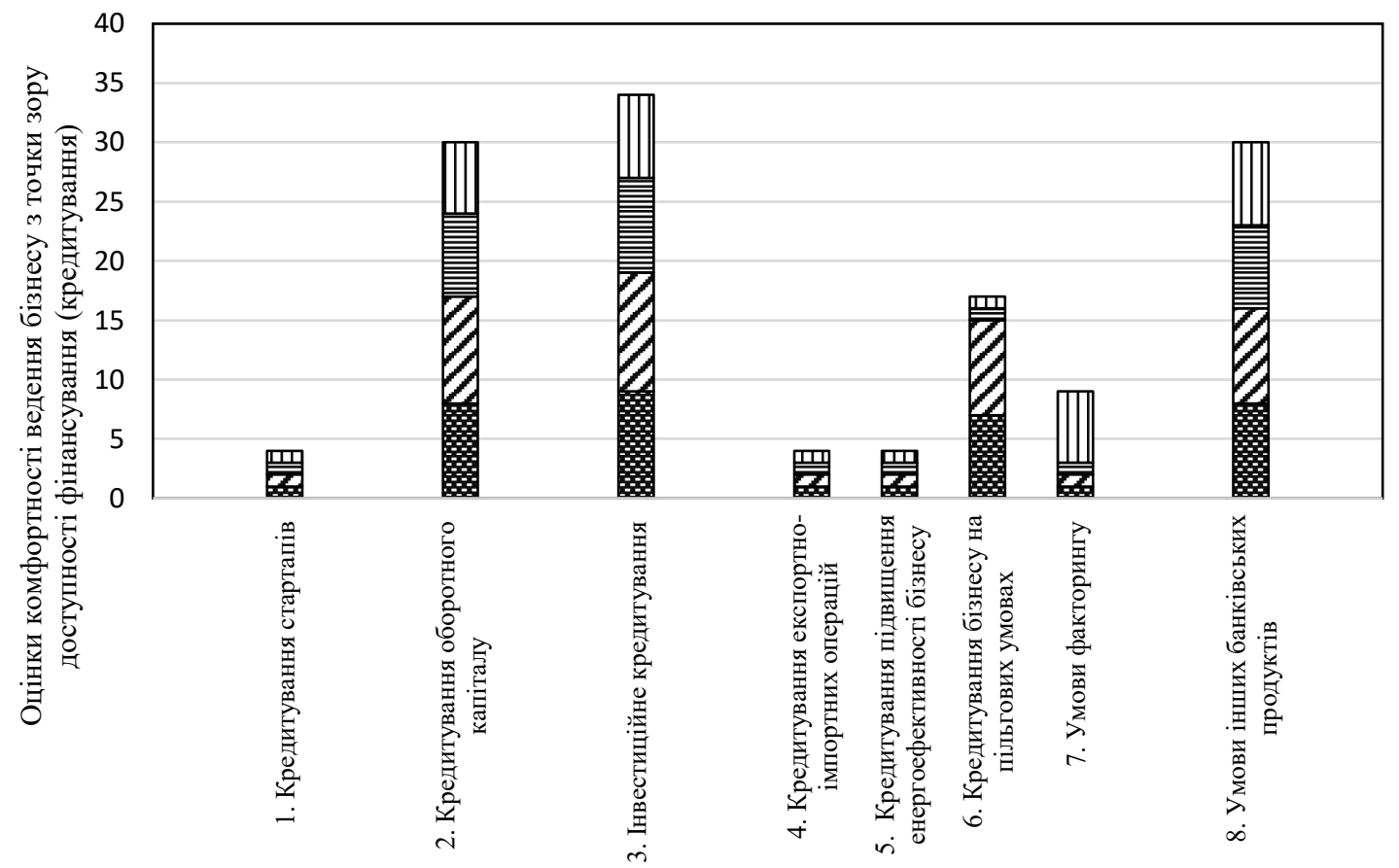

Критерії оцінювання

*складено на основі [9], [10], [11], [12]

Рисунок 5 - Оцінка комфортності ведення бізнесу з точки зору доступності фінансування (кредитування) за кожним досліджуваним банком у м. Вінниці

Фінансова підтримка малого бізнесу з боку місцевого самоврядування може реалізовуватися на основі здійснення в рамках місцевих бюджетних програм безповоротних інвестицій, кредитування бізнес-проектів, сприятливі умови участі у конкурсі щодо отримання кредитування, відшкодування вартості банківського кредитування бізнес-проектів, анонсування у ЗМІ проведення закупівель бюджетним 
коштом, заходи для заохочення бізнесу до участі у бюджетних закупівлях (рис. 6). Відповідно до оцінювання, найкращі оцінки отримано по сприятливим умовам участі у конкурсі щодо отримання кредитування (6 балів), за кредитування бізнес-проектів (7 балів) та за відшкодування вартості банківського кредитування бізнес-проектів (8 балів). За підсумком оцінювання Вінниця набрала 30 балів з можливих 60-ти.

Малі підприємства потребують підтримки влади як невід’ємна частини економічного сектору громади, в тому числі, й для забезпечення доступу до ринків і надбання навичок, необхідних для підвищення конкурентоспроможності. Результати оцінювання комфортності ведення бізнесу з точки зору доступності фінансування за рахунок існування відповідних місцевих бюджетних програм та закупівель у м. Вінниці наведено на рис. 6.

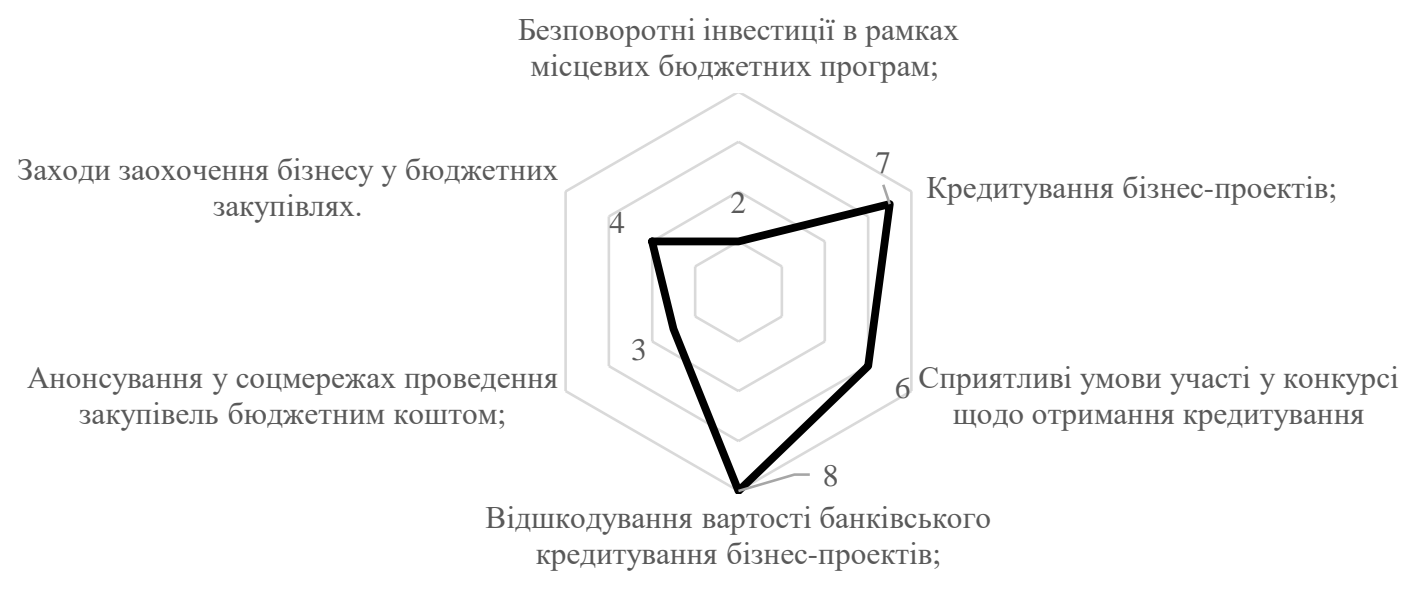

*складено на основі [13]

Рисунок 6 - Оцінка комфортності ведення бізнесу з точки зору доступності фінансування (місцеві бюджетні програми, закупівлі) у відділі розвитку підприсмництва міської ради м. Вінниці

Оцінка комфортності ведення бізнесу з точки зору участі в цих процесах бізнесасоціацій проаналізовано наступні організації м. Вінниці:

1. ВМГО «Центр підтримки малого бізнесу»;

2. ГО «Клуб ділових людей»;

3. Подільська агенція регіонального розвитку ;

4. ГО «Спілка підприємців «Стіна».

Проведений аналіз показав, що у м. Вінниці є досвід формування бізнес-об'єднань, проте громада перебуває лише на початковому етапі використання таких асоціацій для вирішення підприємницьких проблем (рис. 7). Подальший розвиток моделей участі бізнес-формувань задля захисту та просування інтересів представників МСП залишається актуальним завданням для бізнес-спільнот та органів влади міста Вінниці. Серед найбільш розвинених видів співучасті $€$ пропозиція міжнародних проектів фінансування бізнесу та практика участі в них. 


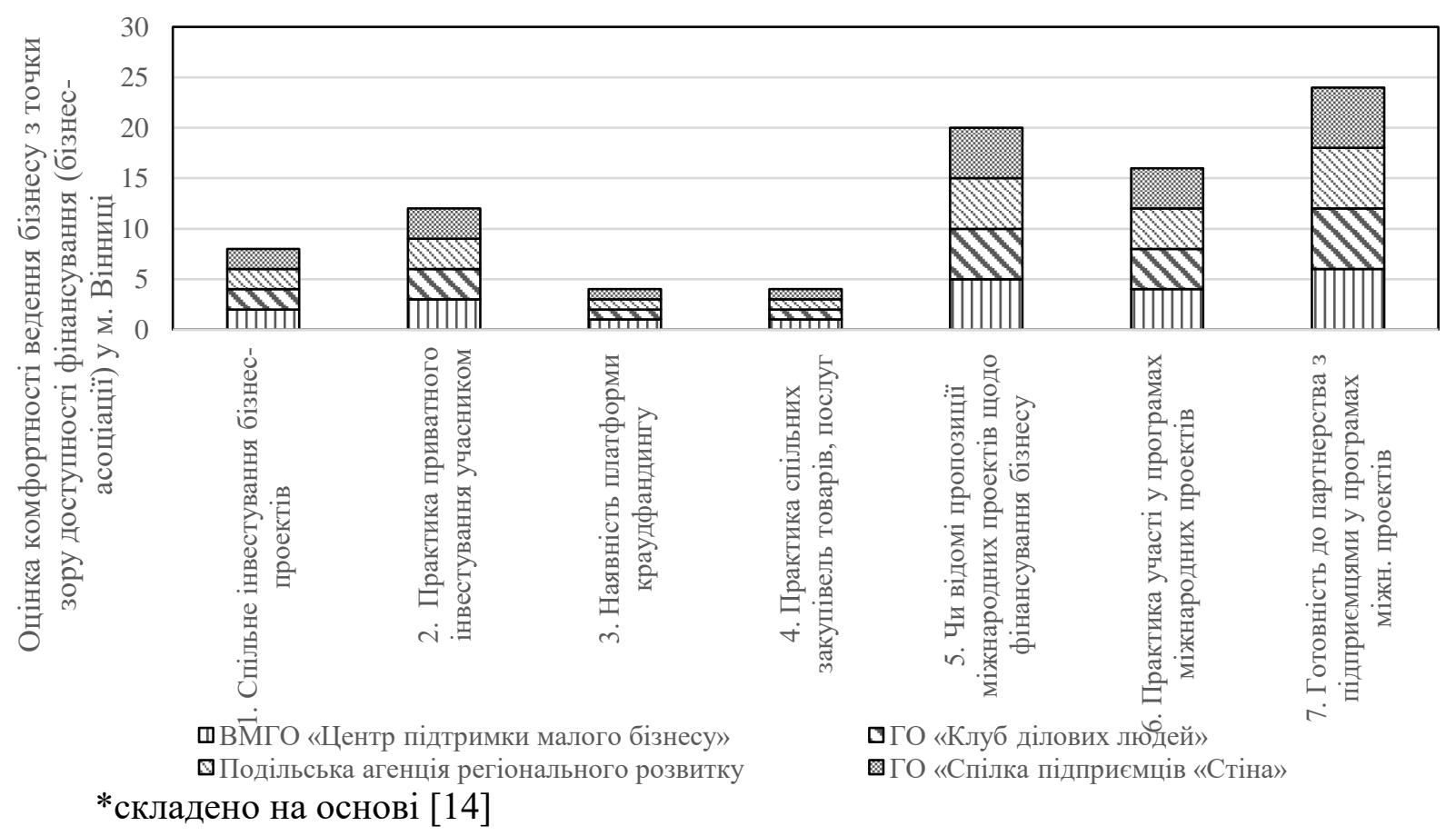

\section{Рисунок 7 - Оцінка комфортності ведення бізнесу $з$ точки зору доступності фінансування (бізнес-асоціації) у м. Вінниці}

Як свідчить світових досвід, доцільність об'єднання в бізнес-асоціації малого і середнього бізнесу викликана наявністю суттєвих переваг спільних зусиль По-перше, асоціація може ефективніше відстоювати права малого бізнесу і легше входити у переговорний процес із органами влади та великими підприємствами, адже «вага» асоціації робить ії повноправним партнером у діалозі. По-друге, це можливість отримати потрібну експертну інформацію у потрібний час. Наприклад, якщо готується законопроект із певної теми, асоціація може дати раціонально обгрунтовані рекомендації, які відображатимуть реальні потреби підприємців. По-третє, асоціації допомагають підприємцям професійно зростати і ставати успішнішими, надаючи їм консалтингові та інші послуги з розвитку бізнесу. Так, за період реалізації проекту ПРООН було розроблено 35 нових послуг, які можуть надавати бізнес-асоціації, ще 17 існуючих послуг - вдосконалено. Число підприємців, охочих отримувати такі послуги, також зросло на 65\%. Підвищення стандартів якості з ініціативи самого бізнесу приносе репутаційні переваги. Така практика також $є$ механізмом протидії недоброчесній конкуренції та корупційним практикам, полегшує доступ на зовнішні ринки завдяки гармонізації 3 міжнародними стандартами, сприяє покращенню екологічності виробництва. Особливість роботи в сфері розвитку бізнес-асоціацій в Україні у тому, що донедавна, не існувало жодної системної навчальної програми для розвитку потенціалу асоціацій. Аби усунути регуляторні перепони для малого бізнесу, у Вінниці, за експертної підтримки ПРООН, запровадили механізм, який дозволяє системно переглядати рішення, що впливають на ведення бізнесу - Відкриту регуляторну платформу. Відкритість означає, що рішення переглядаються колегіально усіма зацікавленими сторонами - міською владою, бізнес-асоціаціями, вищими навчальними закладами та громадськими організаціями. Як результат, у 2018 р. міськрада Вінниці 
скасувала 10 регулювань, які втратили свою актуальність. Додатковою перевагою створення бізнес-асоціацій можуть бути ініціативи, спрямовані на покращення стандартів якості. Зрештою, такий підхід виявляється виграшним для всіх: бізнес здобуває репутацію та маркетингові переваги, покращується безпека для клієнтів, а ще це реальний вплив на вирішення питань громадського здоров'я. Проект Програми розвитку ООН в Україні «Зміцнення бізнес-об’єднань малих і середніх підприємств» впроваджувався за фінансової підтримки Державного секретаріату Швейцарії 3 економічних питань (SECO).

Висновки та перспективи подальших досліджень. На основі проведеної оцінки комфортності ведення бізнесу з точки зору доступності фінансування (кредитування) м. Вінниці було виявлено нерозвиненість банківських продуктів таких, як: кредитування стартапів, кредитування експортно-імпортних операцій, підвищення енергоефективності бізнесу та факторинг. Підсумовуючи результати проведеного дослідження, можна зробити висновок, що на сьогоднішній час 3 боку фінансового забезпечення інвестиційної діяльності, а саме, для відкриття та розвитку малого бізнесу як в Україні, так і в регіонах, поки відсутні дієві та ефективні механізми. Для покращення доступу МСП до фінансування необхідне:

- розвиток інфраструктури довгострокового фінансового забезпечення малого бізнесу на основі посилення конкуренції на регіональному банківському i небанківському кредитному ринку;

- підтримка альтернатив, які можуть скласти конкуренцію банківському фінансуванню, шляхом впровадження відповідної нормативно-правової бази в сфері небанківських фінансових продуктів і послуг;

- зміцнення фінансової грамотності населення та розвиток навичок власників малих підприємств у сфері управління фінансами та бізнес-планування.

\section{СПИСОК ВИКОРИСТАНИХ ДЖЕРЕЛ}

1. Рекуненко I. І. Характеристика елементів інфраструктури фінансового ринку. Вісник Української академії банківської справи. 2014. № 1(36). С. 38-44.

2. Кугій А. А., Сокотенюк С. М. Структурний аналіз фінансового забезпечення малого підприємництва URL: http://nbuv.gov.ua/UJRN/evntukpi_2015_12_36

3. Гацька Л. П., Журавський В. Л. Проблеми фінансового забезпечення малого бізнесу в Україні: Вісник Київського національного університету імені Тараса Шевченка. 2005. №80. 37-40 c.

4. SME Policy Index Eastern Partner Countrie 2016 Assessing the Implementation ofthe Small Business Act for Europ. URL: https://read.oecd-ilibrary.org/development/sme-policy-indexeastern-partner-countries-2016_9789264246249-en\#page1 (дата звернення: 19.11.2019).

5. ПРОЕКТ ПОРЯДКУ ДЕННОГО ІНДЕКС ПОЛІТИКИ ЩОДО МСП: КРАЇНИ СХІДНОГО ПАРТНЕРСТВА. URL: https://www.oecd.org/eurasia/competitivenessprogramme/SMEPI_Launch_Agenda_UA.pdf (дата звернення: 18.11.2019).

6. Національний банк України. Офіційний сайт. URL: http://www.bank.gov.ua

7. Державна служба статистики України. Офіційний сайт. URL: http://www.ukrstat.gov.ua/ (дата звернення: 18.10.2019).

8. Офіційний сайт проекту міжнародної технічної допомоги «Партнерство для розвитку міст» (Проект ПРОMIC). URL: http://pleddg.org.ua/ua/pro-promis/fokus-promis/ (дата звернення: 20.10.2019).

9. Офіційний сайт АТ КБ «Приватбанк». URL: https://privatbank.ua/business/kredit (дата звернення: 19.10.2019). 
10. Офіційний сайт АТ «ОЩАДБАНК».

https://www.oschadbank.ua/ua/business/finansuvannya-biznesu (дата звернення: 19.10.2019).

11. Офіційний сайт банку Укрсиббанк. URL: https://my.ukrsibbank.com/ua/personal/ (дата звернення: 19.10.2019).

12. Офіційний сайт «Альфа-Банку». URL: https://alfabank.ua/ (дата звернення: 19.10.2019).

13. Офіційний сайт Вінницької міської ради. URL: https://www.vmr.gov.ua/Branches/Lists/BusinessSupport/ShowContent.aspx?ID=13 (дата звернення: 19.10.2019).

14. Програма посилення конкурентоспроможності малого та середнього підприємництва вінницької міської об'єднаної територіальної громади на 2017-2020 роки. URL:https://www.vmr.gov.ua/Branches/Lists/BusinessSupport/ShowContent.aspx?ID=12 (дата звернення: 23.10.2019).

15. New Approaches to SME and Entrepreneurship Financing: Broadening the Range of Instruments . [Electronicresource]. https://www.oecd.org/cfe/smes/New-Approaches-SME-full-report.pdf (дата звернення: 25.10.2019).

16. Рекуненко I. I. Інфраструктура фінансового ринку України: сучасний стан та перспективи розвитку: монографія. Суми: ДВНЗ “УАБС НБУ”, 2013. - 411 с. 